\title{
The Piltdown case: Further questions
}

AUTHOR:

J. Francis Thackeray ${ }^{1}$

\section{AFFILIATION:}

${ }^{1}$ Evolutionary Studies Institute, School of Geosciences, University of the Witwatersrand, Johannesburg, South Africa

\section{CORRESPONDENCE TO: \\ J. Francis Thackeray}

EMAIL:

Francis.Thackeray@wits.ac.za

\section{KEYWORDS:}

Piltdown Man; forensic analyses; palaeontology; Sussex; Teilhard de Chardin

\section{HOW TO CITE:}

Thackeray JF. The Piltdown case: Further questions. S Afr J Sci. 2016;112(9/10), Art. \#a0170, 2 pages. http://dx.doi. org/10.17159/sajs.2016/a0170

(C) 2016. The Author(s). Published under a Creative Commons Attribution Licence.
About 60 years ago, a South African anatomist, Joseph Weiner, published a book entitled The Piltdown Forgery ${ }^{1}$, exposing a hoax that had been perpetrated about 100 years ago at the site of Piltdown in Sussex, England. The announcement of 'Piltdown Man' - classified as Eoanthropus dawsoni and believed to be a hominid apparently associated with Pleistocene fauna - had been made by Smith Woodward of the British Museum (Natural History) at Burlington House in London on 18 December 1912. However, it turned out that the 'hominid' was a fabrication in which a subfossil human cranium and a modern orangutan jaw (both stained brown) were placed together in a gravel pit, thereby confusing palaeontologists. In the process, Raymond Dart's announcement of the 'Taung Child' (Australopithecus africanus) from South Africa was disregarded by many (including the anatomist Sir Arthur Keith) who questioned Dart's claim that this small-brained fossil represented a genuine Pleistocene hominid.

Weiner, together with his colleagues Kenneth Oakley (Keeper of Palaeontology at the British Museum) and Sir Wilfred Le Gros Clark, recognised the forgery. After investigation, they concluded that Charles Dawson (a lawyer and amateur archaeologist based in Sussex) was the prime suspect responsible for the forgery. This conclusion has been endorsed recently by Isabelle de Groote and her palaeoanthropologist colleagues ${ }^{2}$ who have undertaken high-tech forensic analyses, including the use of micro-CT scanning of teeth and DNA analyses of the craniodental material. They conclude that only a single hoaxer was responsible, namely Dawson, now known to have been responsible for more than 30 forgeries, perhaps in the hope of earning him the distinction of being elected as a Fellow of the Royal Society (which he never attained).

In the light of the recent forensic analyses, one may well accept a verdict that Dawson was indeed the sole perpetrator: once and for all, Piltdown case closed.

But is it closed? Several people other than Dawson have been questioned, because they were perhaps directly implicated or knew about the forgery. As shown by Thackeray ${ }^{3}$, Robert Essex, Louis Leakey, Stephen Jay Gould and Thackeray himself have all been suspicious of Pierre Teilhard de Chardin, a French Jesuit palaeontologist who was known to have been a 'joker', and who was based at Ore Place, a theological seminary near Hastings in Sussex, within $50 \mathrm{~km}$ of Piltdown where Teilhard de Chardin contributed to excavations in 1912 (when he found a fossil elephant molar) and again in 1913 when he found the orangutan canine (assumed to be a hominid associated with the human cranium).

Some details are pertinent here. In the first week of January 1913, Teilhard de Chardin wrote an essay in Etudes beginning with the words 'There was a time when La Prehistoire deserved to be suspect, and the subject of jokes'. His entire essay is about the current understanding of human evolution, but most strangely (and suspiciously) he omits all reference to Piltdown even though it had been officially announced to great acclaim just 3 weeks earlier. Almost immediately after that announcement, Teilhard de Chardin wrote to his friend Felix Pelletier (with whom he had collected fossils in Sussex), saying: 'We must do nothing. We must wait for the criticisms that will follow. Marcellin Boule [an eminent French prehistorian] will not be taken in.' This essentially convinced Thackeray ${ }^{3}$ that Teilhard de Chardin knew from the very beginning that 'Piltdown Man' was not genuine.

In 1977, Oakley told Thackeray that he was giving Teilhard de Chardin the benefit of the doubt because he was a priest. But Teilhard de Chardin was a Jesuit, whom Phillip Tobias called a 'joker', and Jesuits were allegedly allowed to lie providing it was a joke. ${ }^{3}$

Teilhard de Chardin and Martin Hinton allegedly said they knew who had been the Piltdown perpetrator, and both were adamant that it was not Dawson. ${ }^{3}$ The question arises - were they 'in on the joke', and was this joke directed against Dawson, especially if some people known to Dawson began to suspect his forgeries (more than 30 of them)?

This idea is relevant to the fact that the Piltdown orangutan jaw is likely to have come from Borneo (as indicated from the recent DNA analyses). ${ }^{2}$ Secondly, it is pertinent to facts presented by Sherratt ${ }^{4}$ who referred to an expedition led by Everett in 1878, when material (including orangutan crania and mandibles) was collected in Borneo and brought back to England. Most if not all of this material was deposited in the British Museum (Natural History), but evidently 'duplicates' could have been distributed elsewhere, subject to the decision of a committee..$^{4}$ It would seem that such 'duplicates' could have been distributed to donors of the expedition, including members of the Willett family who lived in Sussex, notably Henry Willett (an antiquarian whose wealth was based on his successful brewery, supplemented by his successful investment in railways); Ernest Willett (who had a strong interest in ancient coins); and Edgar Willett who was trained at Oxford, practised as an anaesthetist, and also served as a curator of a museum with expertise in anatomy.

On the death of Henry Willett, his son Edgar appears to have taken early retirement and enjoyed the life of a gentleman in Sussex, pursing his pleasure in sport and croquet. And here is the rub: he is known to have accompanied Dawson at Piltdown.

There is strong reason to be interested in the Willett family, especially Edgar Willett whose background in anatomy is intriguing, and his association with Dawson at Piltdown is remarkable. As the Willetts (among others, including Darwin) had provided funds for the Everett expedition to Borneo, it would seem entirely possible that a 'duplicate' orangutan mandible from that expedition found its way into the family's collections.

The family name Willett is strongly associated with Ore in Sussex, and Ore Place in Ore (near Hastings in Sussex) is where Teilhard de Chardin was based between 1908 and 1912, the very years in which Piltdown material was initially collected. Work resumed in August 1913 when Teilhard de Chardin was invited to assist in excavations, and when he found the canine. The question now arises as to whether the French Jesuit knew about a Piltdown joke 
through one of the Willetts, perhaps Edgar Willett who (as an anatomist) could have been in a position to facilitate a joke against Dawson, potentially with Teilhard de Chardin as an adviser.

Thackeray ${ }^{3}$ has contended that Teilhard de Chardin may have wanted the Piltdown joke to be exposed without damaging his future career in palaeontology. When he was invited to Piltdown in August 1913, to continue excavations, he may have 'discovered' the reddish-brown canine in a deliberate attempt to expose the whole thing as a joke. However, he found the canine in an area that had already been thoroughly searched in the exposed gravels. Woodward had initially expressed disbelief that he had found the canine there, but was subsequently taken in.

Gould $^{5}$ was strongly suspicious of Teilhard de Chardin, especially because the French palaeontologist had stated in 1920 that the condyle of the Piltdown mandible might have been deliberately broken. In Gould's view, this statement was tantamount to an admission that Teilhard de Chardin knew of the forgery although such a thing was not suspected at the time.

Thackeray ${ }^{3}$ has referred to two letters that Teilhard de Chardin wrote shortly before his death in 1955, after exposure of the hoax. In a letter to Oakley dated 28 November 1953, Teilhard de Chardin writes:

Would it have been impossible for some collector who had in his possession some ape bones, to have discarded specimens into the pit? The idea sounds fantastic. But, in my opinion, no more fantastic than to make Dawson the perpetrator of the hoax.

Similarly, on 8 December 1953, Teilhard de Chardin wrote to Abbe Henri Breuil, saying:

I have difficulty in accepting a hoax [supercherie] on the part of Dawson (a close friend of Smith Woodward). And as fantastic as it seems, I admitted rather that someone threw, innocently, from the cottage nearby, some 'collection' in the 'Pit' of Piltdown.

The question arises: was Teilhard de Chardin referring to an actual 'collection' of material that had been in the hands of 'some collector' including a member of the Willett family - perhaps Edgar Willett, an anatomist and a man of leisure in Sussex, who knew Dawson?

Thackeray ${ }^{3}$ refers to a letter that was allegedly written by Teilhard de Chardin and deposited in a bank, with instructions that it be opened only after his death. No such letter was announced after his death. He died in New York when he was based there, at the Wenner Gren Foundation. Leslie Aiello (current President of the Foundation) told Thackeray (written communication, 2016 September 07) that Teilhard de Chardin's documents were removed from his office by Jesuits after his death, and bank details are not available. Please could someone try to find out where Teilhard de Chardin did his banking transactions before his death in New York? This might truly and finally bring the Piltdown case to a close.

\section{References}

1. Weiner JS. The Piltdown forgery. London: Oxford University Press; 1955.

2. De Groote I, Girdland Flink L, Abbas R, Bello SM, Burgia L, Buck LT, et al New genetic and morphological evidence suggests a single hoaxer created 'Piltdown man'. R Soc Open Sci. 2016;3, Art. \#160328, 14 pages. http:// dx.doi.org/10.1098/rsos.160328

3. Thackeray JF. Deceiver, joker or innocent? Teilhard de Chardin and Piltdown Man. Antiquity. 2012;86:228-234. http://dx.doi.org/10.1017/ S0003598X0006258X

4. Sherratt A. Darwin among the archaeologists: The John Evans nexus and the Borneo Caves. Antiquity. 2002;76(291):151-157. http://dx.doi.org/10.1017/ S0003598X00089924

5. Gould SJ. The Piltdown conspiracy. Natural History Magazine. 1980;89:8-28. 